\title{
Effects of the different Supported Structures on Tubular Solid Oxide Fuel Cell Performance
}

\author{
Zidong $\mathrm{Yu}^{1,2, *}$, Shengji Liu ${ }^{1, *}$, Fa Zheng ${ }^{3}$, Yuhong Ding ${ }^{3}$
}

${ }^{1}$ School of Automobile and Traffic Engineering, Jiangsu University, Zhenjiang, Jiangsu 212013, China;

${ }^{2}$ School of Energy and Power Engineering, Jiangsu University of Science and Technology, Zhenjiang, Jiangsu 212003, China.

*E-mail: yuzidong@just.edu.cn

${ }^{3}$ Jiangsu Zhongjing New Energy Science \& Technology Research Center, Zhenjiang, Jiangsu 212013, China.

doi: $10.20964 / 2016.12 .53$

Received: 4 September 2016 / Accepted: 18 October 2016 / Published: 10 November 2016

A comprehensive two-dimensional model has been developed to investigate the performance of tubular solid oxide fuel cell (T-SOFC) stack with different supported structures. The discrepancy between the anode-supported tubular SOFC (AST-SOFC) stack and the cathode-supported tubular SOFC (CST-SOFC) stack are examined by varying temperature, electrical conductivity, porosity, contact resistance and output voltage. The results illustrate that the different supported structures have an significant influence on the performance of stack. The performance of CST-SOFC stack is much better than AST-SOFC stack for any aforementioned working parameters. Especially in lower temperature, smaller cathode conductivity, larger cathode porosity and lower output voltage, the advantage is more outstanding.

Keywords: Tubular solid oxide fuel cell; Electrode support; Structure comparison

\section{FULL TEXT}

(C) 2016 The Authors. Published by ESG (www.electrochemsci.org). This article is an open access article distributed under the terms and conditions of the Creative Commons Attribution license (http://creativecommons.org/licenses/by/4.0/). 